\title{
Effect of cervical headgear on dental arch area, shape and interarch dimensions
}

\author{
A randomized study \\ Toni Heino ${ }^{1}$. Heta Kokko ${ }^{1}$ Ville Vuollo', ${ }^{1,2}$ Pertti Pirttiniemi ${ }^{1,2}$ \\ Received: 28 March 2019 / Accepted: 14 October 2020 / Published online: 3 December 2020 \\ (c) The Author(s) 2020
}

\begin{abstract}
Purpose The goal was to study the effects of early cervical headgear treatment on maxillary and mandibular dental arch area, shape and interarch dimensions.

Methods The total study group comprised 67 children aged 7.6 years (standard deviation 0.3) with Angle class II malocclusion collected between 1992 and 1996. The children were randomly divided into two groups of equal size. In the first group, cervical headgear treatment was started immediately and undertaken for 2 years. The remaining patients served as untreated controls. Dental casts were taken and scanned at the beginning of treatment (T0) and at the 2-year (T1) and 4-year follow-up (T2). Three-dimensional landmarks describing the positions of maxillary and mandibular incisors, canines, first and second premolars and first molars were used to calculate and visualize the maxillary and mandibular dental arch area and shape using the polynomial equation $y=A x^{6}+B x^{2}$.

Results Significant changes in the shape and area of both maxillary and mandibular dental arches were induced with cervical headgear. The headgear increased dental arch area, sagittal dimensions at the mid-sagittal line and transversal dimensions at all of the measured levels in both dental arches compared to the control group.

Conclusions Cervical headgear is an effective treatment device to gain space in both dental arches. Furthermore, when used as an early phase treatment, relapse is relatively small compared to the gained space.
\end{abstract}

Keywords Angle class II malocclusion · Space gain · Molars · Growth · Orthodontic treatment

Pertti Pirttiniemi

pertti.pirttiniemi@oulu.fi

1 Research Unit of Oral Health Sciences, Faculty of Medicine, University of Oulu, Oulu, Finland

2 Medical Research Center, Oulu University Hospital, Oulu, Finland 


\section{Wirkung eines zervikalen Headgears auf den Zahnbogenbereich, die Form und die Dimensionen zwischen den Zahnbögen}

Eine randomisierte Studie

\section{Zusammenfassung}

Zielsetzung Ziel dieser Studie war es, die Auswirkungen einer frühen zervikalen Headgear-Behandlung auf den Bereich des Ober- und Unterkieferzahnbogens, die Form und die Interbogendimensionen zu untersuchen.

Methoden Die Studiengruppe umfasste insgesamt 67 Kinder im Alter von 7,6 Jahren (Standardabweichung 0,3) mit Angle-Klasse-II-Malokklusion, die zwischen 1992 und 1996 behandelt wurden. Die Kinder wurden randomisiert in 2 gleich große Gruppen aufgeteilt. In der ersten Gruppe wurde sofort mit der zervikalen Headgear-Behandlung begonnen und sie wurde 2 Jahre lang durchgeführt. Die übrigen Patienten dienten als unbehandelte Kontrolle. Zu Beginn der Behandlung (T0), beim 2- (T1) und beim 4-Jahres-Follow-up (T2) wurden Abdrücke genommen und gescannt. Dreidimensionale Landmarken zur Darstellung der Positionen von Schneidezähnen, Eckzähnen, ersten und zweiten Prämolaren und ersten Molaren im Ober- und Unterkiefer wurden zur Berechnung und Visualisierung des Bereichs und der Form des Zahnbogens des Ober- und Unterkiefers unter Verwendung der Polynomgleichung $y=A x^{6}+B x^{2}$ verwendet.

Ergebnisse Mit dem zervikalen Headgear wurden signifikante Veränderungen in Form und Fläche sowohl der Ober- als auch der Unterkieferzahnbögen induziert. Das Headgear vergrößerte im Vergleich zur Kontrollgruppe die Zahnbogenfläche, die sagittalen Dimensionen an der mittleren sagittalen Linie und die transversalen Dimensionen auf allen gemessenen Ebenen in beiden Zahnbögen.

Schlussfolgerungen Das zervikale Headgear ist eine wirksame Behandlungsvorrichtung, um in beiden Zahnbögen Platz zu gewinnen. Wenn sie als Frühphasentherapie eingesetzt wird, ist das Rezidiv im Vergleich zum gewonnenen Platz relativ gering.

Schlüsselwörter Angle-Klasse-II-Malokklusion · Platzgewinn · Molaren · Wachstum · Kieferorthopädische Behandlung

\section{Background}

The headgear is a widely used orthodontic appliance for treating Angle class II malocclusion and for distalizing upper molars [1]. It is also a fundamental orthodontic appliance to optimize anchorage for space closure [2]. The headgear should be used $12-14 \mathrm{~h}$ per day to achieve sufficient results with treatment [3].

Studies on treatment with cervical headgear combined with fixed appliances have shown an inhibition of forward movement of the maxilla and a posteroinferior redirection of its growth. In addition, downward and backward rotation of the mandible and an improvement of the maxillomandibular relationship was observed together with anterior downward tipping of the palatal plane, palatal tipping of the maxillary incisors, extrusion and distal tipping of the maxillary first molars, reduction of overjet and overbite, and improvement of molar relationship [4]. The headgear also induces molar rotation which results in increased dental arch length. Because of physiological tooth eruption and movement, loss of primary teeth, normal growth and orthodontic movement occur in parallel, it is challenging to define reference points and therefore to reliably study the rotation and movement of the molars [3].

Especially the rotation of molars gains space and lengthens the dental arch. Studies are still controversial since some studies showed only about $1 \mathrm{~mm}$ of space gain, whereas some others showed a variation between 2 and $3 \mathrm{~mm}$. According to some studies, space gain can be even more than $3 \mathrm{~mm}$ for the total dental arch [3]. Kirjavainen et al. in their study presented children who had severe, moderate or mild maxillary crowding and also mandibular crowding. The use of a headgear resulted in good teeth alignment and enough space gain for all teeth for practically all children [5]. Mäntysaari et al. showed that the space gain in the mandible was approximately half of that in the maxilla [6].

Even though there is long experience and many studies were done with the headgear, the optimal timing of headgear treatment remains controversial. The aim in early treatment is to make later treatment simpler and to avoid extractions [7]. In the study of Kirjavainen et al. 52\% of the patients needed phase 2 treatment after cervical headgear therapy mostly because of excess overjet and overbite [5]. The study by Mäntysaari et al. analogously showed that early use of the headgear did not significantly affect overbite or overjet. Tulloch et al. found that there was little difference in the effectiveness of early and later treatment for the correction of class II malocclusion. Headgear treatment was, however, more efficient if started before the eruption of the second maxillary molars [8]. When it comes to treatment's results and success rate, it seems that expected growth and patient cooperation play a major role [7].

The aim of this study was to determine the effects of early cervical headgear treatment on maxillary and 
mandibular dental arch area, shape, and interarch dimensions.

\section{Materials and methods}

The material for this study was collected between 1992 and 1996. Informed consent was received from all parents. The existing legislation concerning ethical approval of the study was taken into account and followed in the study. The material comprised 67 children (28 females and 39 males) with a class II malocclusion. The children were randomly divided into two groups. In the first group, Kloehn-type cervical headgear treatment with $6.9-9.8 \mathrm{~N}$ force was started immediately or after eruption of the first maxillary molars (mean age 7.3 years, standard deviation [SD] 0.53). The inner bow of the headgear was expanded and constantly held $10 \mathrm{~mm}$ wider than the dental arch.

Treatment with the headgear was performed until full class I occlusion was achieved bilaterally. After that, the headgear was worn for retention purpose with less use, until two years of treatment were achieved. In the control group, only minor interceptive procedures were performed during the follow-up period. Fixed appliance treatment, if needed, including extraction of permanent teeth due to crowding, was undertaken after the completion of early treatment. Records were available from the start of the early treatment and at a follow-up after 2 and 4 years. The data are described in more detail in an earlier study by Pirttiniemi et al. [9]. Headgear treatment was undertaken for 2 years a

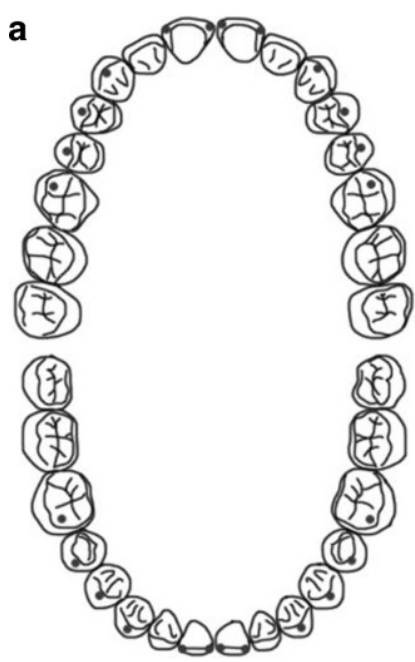

b

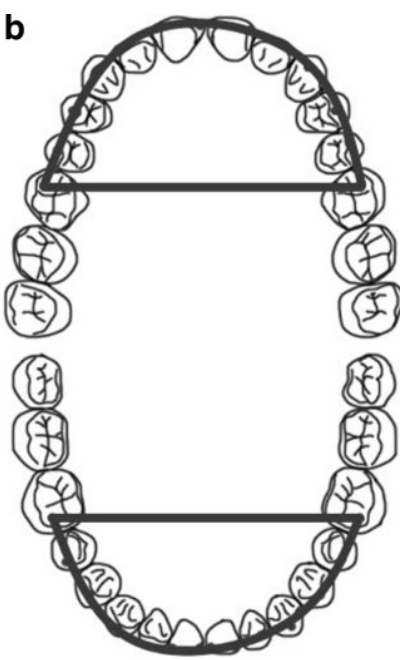

Fig. 1 a Measurement points (marked with dots) of incisors, canines, 1 st and 2nd premolars, and 1st molars. b Dental arch areas on occlusal surface in both maxillary and mandibular dental arches

Abb. 1 a Messstellen (mit Punkten markiert) von Schneidezähnen, Eckzähnen, ersten und zweiten Prämolaren und ersten Molaren. b Zahnbogenbereiche auf der Okklusalfläche in Ober- und Unterkieferzahnbögen from T0 to T1. In this study, we focused on the first 2 years of treatment and the follow-up period of another 2 years.

Dental casts were taken and scanned with 3Shape R700 Dental 3D scanner (3Shape, Copenhagen, Denmark) from both groups at the beginning of treatment $\mathrm{T} 0$, at the 2-year follow-up (T1) and at the 4-year follow-up (T2). Nine casts had to be excluded from the measurements due to unsuccessful 3D scanning, missing casts, missing teeth, or infraocclusal teeth. Due to these exclusions, the population varies between the groups at $\mathrm{T} 0, \mathrm{~T} 1$, and $\mathrm{T} 2$. The studied groups at given measurement times are shown in the result tables.

The 3D landmarks describing the positions of maxillary and mandibular incisors, canines, first and second premolars and first molars were used to calculate the characteristics of the maxillary and mandibular dental arches (Fig. 1a). These landmarks were the following: mesial tips of the incisors, buccal cusps of the canines and premolars and mesiobuccal cusps of the first molars. In the case of a missing tooth, the landmark was not placed. After landmarking, the occlusal plane was defined by three landmarks on the maxillary teeth. These landmarks were the following: mesial tips of the central incisors and both mesiobuccal cusps of first molars. Next, all landmarks were projected orthogonally on the occlusion plane. A polynomial equation $y=A x^{6}+B x^{2}$
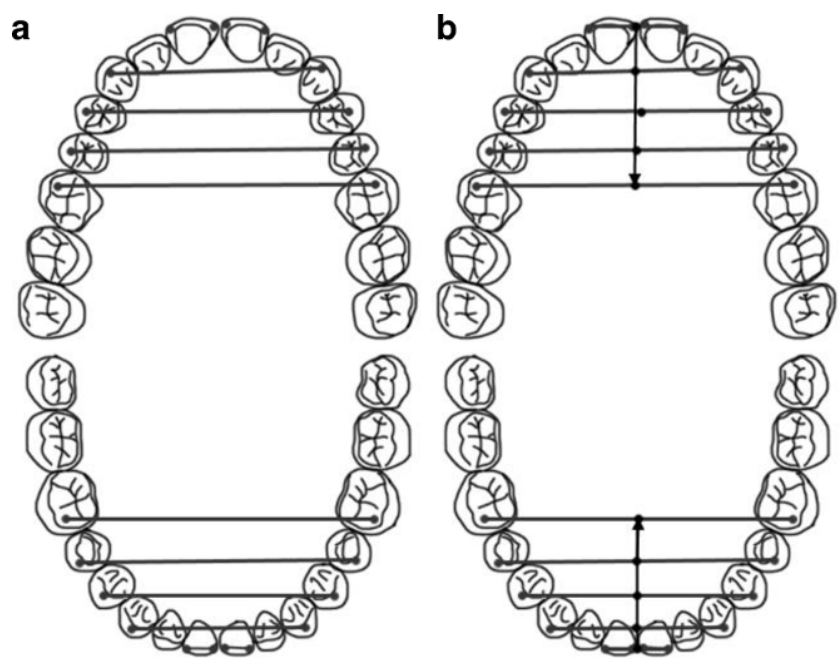

Fig. 2 a Measurement of the transversal dimension of the dental arch at canine-canine, 1st premolar-1st premolar, 2nd premolar-2nd premolar, 1st molar-1st molar levels in the maxillary and mandibular dental arches. b Measurement of the sagittal dimensions of the dental arch between incisor-1st molar, canine-1st molar, 1st premolar-1st molar, 2nd premolar-1st molar

Abb. 2 a Messung der transversalen Dimension des Zahnbogens: Eckzahn-Eckzahn, erster Prämolar - erster Prämolar, zweiter Prämolar zweiter Prämolar, zweiter Prämolar - zweiter Prämolar, erster Molar erster Molar im Ober- und Unterkieferzahnbogen. b Messung der sagittalen Dimensionen des Zahnbogens: Schneidezahn - erster Molar, Eckzahn - erster Molar, erster Prämolar - erster Molar, zweiter Prämolar - erster Molar 
Table 1 Mean dental arch area, mean width of the dental arch at 1st molar level, and mean depth of the dental arch from T0 to T2

Tab. 1 Mittlere Zahnbogenfläche, mittlere Breite des Zahnbogens auf Höhe des ersten Molaren und mittlere Tiefe des Zahnbogens von T0 bis T2

\begin{tabular}{|c|c|c|c|c|c|c|c|c|}
\hline \multicolumn{2}{|c|}{ Mean dental arch area } & & \multicolumn{3}{|c|}{ Headgear } & \multicolumn{3}{|c|}{ Control } \\
\hline & & & $N$ & Area, $\mathbf{m m}^{2}$ & $\mathrm{SD}, \mathbf{m m}^{2}$ & $N$ & Area, $\mathbf{m m}^{2}$ & $\mathrm{SD}, \mathrm{mm}^{2}$ \\
\hline \multirow[t]{6}{*}{ T0 } & Both & Maxillary & 28 & 1070.1 & 92.5 & 34 & 1052.0 & 88.3 \\
\hline & Female & & 12 & 1031.4 & 102.3 & 14 & 1003.2 & 55.6 \\
\hline & Male & & 16 & 1099.2 & 75.1 & 20 & 1086.1 & 91.9 \\
\hline & Both & Mandibular & 28 & 851.5 & 83.0 & 34 & 849.0 & 78.3 \\
\hline & Female & & 13 & 819.1 & 83.6 & 14 & 805.0 & 75.8 \\
\hline & Male & & 15 & 879.6 & 73.9 & 20 & 879.8 & 65.5 \\
\hline \multirow[t]{6}{*}{$\mathrm{T} 1$} & Both & Maxillary & 29 & 1189.3 & 153.9 & 35 & 1055.0 & 112.0 \\
\hline & Female & & 13 & 1135.2 & 195.7 & 15 & 998.2 & 100.9 \\
\hline & Male & & 16 & 1233.2 & 94.7 & 20 & 994.5 & 126.1 \\
\hline & Both & Mandibular & 28 & 910.8 & 111.6 & 34 & 827.2 & 85.8 \\
\hline & Female & & 11 & 867.0 & 85.9 & 15 & 784.3 & 88.1 \\
\hline & Male & & 17 & 939.2 & 119.2 & 19 & 861.1 & 68.6 \\
\hline \multirow[t]{6}{*}{$\mathrm{T} 2$} & Both & Maxillary & 28 & 1202.5 & 106.5 & 34 & 1071.3 & 140.5 \\
\hline & Female & & 11 & 1167.0 & 100.7 & 14 & 1097.6 & 102.4 \\
\hline & Male & & 17 & 1225.5 & 106.7 & 20 & 1125.0 & 126.5 \\
\hline & Both & Mandibular & 26 & 891.7 & 110.5 & 31 & 809.6 & 91.6 \\
\hline & Female & & 11 & 839.1 & 105.4 & 12 & 767.5 & 85.9 \\
\hline & Male & & 15 & 930.3 & 100.5 & 19 & 836.1 & 86.8 \\
\hline \multirow{2}{*}{\multicolumn{2}{|c|}{ Width }} & & \multicolumn{3}{|c|}{ Headgear } & \multicolumn{3}{|c|}{ Control } \\
\hline & & & $N$ & Width, mm & $\mathrm{SD}, \mathbf{m m}$ & $N$ & Width, mm & $\mathrm{SD}, \mathrm{mm}$ \\
\hline \multirow[t]{6}{*}{ T0 } & Both & Maxillary & 28 & 49.6 & 2.3 & 34 & 49.0 & 2.2 \\
\hline & Female & & 12 & 48.0 & 1.6 & 14 & 48.5 & 2.9 \\
\hline & Male & & 16 & 50.5 & 2.2 & 20 & 49.4 & 1.5 \\
\hline & Both & Mandibular & 28 & 44.2 & 2.1 & 34 & 44.4 & 1.7 \\
\hline & Female & & 13 & 43.3 & 2.2 & 14 & 43.4 & 1.7 \\
\hline & Male & & 15 & 45.0 & 1.6 & 20 & 45.1 & 1.4 \\
\hline \multirow[t]{6}{*}{$\mathrm{T} 1$} & Both & Maxillary & 29 & 54.2 & 2.9 & 35 & 49.9 & 2.0 \\
\hline & Female & & 13 & 53.3 & 3.2 & 15 & 49.1 & 2.3 \\
\hline & Male & & 16 & 54.9 & 2.6 & 20 & 50.5 & 1.5 \\
\hline & Both & Mandibular & 28 & 47.2 & 2.1 & 34 & 44.5 & 1.7 \\
\hline & Female & & 11 & 46.3 & 1.4 & 15 & 43.9 & 1.6 \\
\hline & Male & & 17 & 47.8 & 2.3 & 19 & 45.0 & 1.5 \\
\hline \multirow[t]{6}{*}{$\mathrm{T} 2$} & Both & Maxillary & 28 & 54.2 & 2.4 & 34 & 50.6 & 2.5 \\
\hline & Female & & 11 & 53.1 & 2.6 & 14 & 49.1 & 2.5 \\
\hline & Male & & 17 & 54.7 & 2.2 & 20 & 51.6 & 1.8 \\
\hline & Both & Mandibular & 26 & 47.2 & 2.1 & 31 & 44.8 & 2.2 \\
\hline & Female & & 11 & 46.1 & 1.9 & 12 & 43.7 & 2.3 \\
\hline & Male & & 15 & 47.8 & 2.2 & 19 & 45.5 & 1.9 \\
\hline \multirow{2}{*}{\multicolumn{2}{|c|}{ Depth }} & & \multicolumn{3}{|c|}{ Headgear } & \multicolumn{3}{|c|}{ Control } \\
\hline & & & $N$ & Depth, mm & SD, mm & $N$ & Depth, mm & $\mathrm{SD}, \mathrm{mm}$ \\
\hline \multirow[t]{6}{*}{ T0 } & Both & Maxillary & 28 & 28.4 & 1.9 & 34 & 28.2 & 1.9 \\
\hline & Female & & 12 & 28.1 & 2.2 & 14 & 27.4 & 1.3 \\
\hline & Male & & 16 & 28.6 & 1.7 & 20 & 28.7 & 2.1 \\
\hline & Both & Mandibular & 28 & 25.7 & 1.8 & 34 & 25.7 & 1.4 \\
\hline & Female & & 13 & 24.9 & 2.1 & 14 & 25.1 & 1.2 \\
\hline & Male & & 15 & 26.3 & 1.2 & 20 & 26.0 & 1.4 \\
\hline
\end{tabular}


Table 1 (Continued)

Tab. 1 (Fortsetzung)

\begin{tabular}{|c|c|c|c|c|c|c|c|c|}
\hline \multirow[t]{6}{*}{$\mathrm{T} 1$} & Both & Maxillary & 29 & 29.9 & 2.9 & 35 & 28.0 & 2.7 \\
\hline & Female & & 13 & 29.0 & 3.8 & 15 & 26.7 & 2.1 \\
\hline & Male & & 16 & 30.7 & 1.7 & 20 & 28.9 & 2.8 \\
\hline & Both & Mandibular & 28 & 26.2 & 1.7 & 34 & 25.2 & 1.8 \\
\hline & Female & & 11 & 25.5 & 2.0 & 15 & 24.5 & 1.4 \\
\hline & Male & & 17 & 27.0 & 1.7 & 19 & 25.8 & 1.9 \\
\hline \multirow[t]{6}{*}{$\mathrm{T} 2$} & Both & Maxillary & 28 & 30.1 & 1.4 & 34 & 28.1 & 3.1 \\
\hline & Female & & 11 & 29.9 & 1.4 & 14 & 26.5 & 2.9 \\
\hline & Male & & 17 & 30.2 & 1.5 & 20 & 29.0 & 3.1 \\
\hline & Both & Mandibular & 26 & 26.0 & 1.8 & 31 & 24.7 & 2.3 \\
\hline & Female & & 11 & 25.2 & 2.0 & 12 & 23.6 & 1.7 \\
\hline & Male & & 15 & 26.7 & 1.5 & 19 & 25.4 & 2.4 \\
\hline
\end{tabular}

$S D$ standard deviation, $T O$ beginning of treatment, $T 1$ the 2-year follow-up, $T 2$ the 4-year follow-up

was fitted to the projected landmarks using the least squares method. A and B are coefficients of the polynomial equation and their values are determined by the least squares fitting. This polynomial equation was chosen to model the dental arch form based on the work of Noroozi et al. [10]. The dental arch area was calculated by integrating the fitted polynomial function. The landmarks and dental arch areas are shown in Fig. 1. The projected landmarks were also used to measure both the transversal and sagittal dimensions, i.e., width and depth of the dental arches (Fig. 2). The mean dental arch areas, the width at the first molar level, and the depth between the incisor and the first molar are shown in Table 1. Landmarking, projecting, polynomial fitting, and all the measuring were executed using Rapidform2006 software (INUS Technology, Inc., Seoul, Korea) and all possible processes were automated with a set of in-house VBA (Visual Basic for Applications) subroutines developed for Rapidform. The measured data were analyzed with SPSS statistical software (version 24.0; IBM, Inc., Chicago, IL, USA). These results were compared between the treatment group and the control group and also between the male and female groups. Independent samples t-test was used to compare the means of the groups after verifying normal distribution of the data.

The geometric accuracy of the 3Shape R700 scanner was verified to be $0.02 \mathrm{~mm}$. Previous studies have proven that landmarking dental 3D models is reliable [11] and the measurements on 3D surfaces have excellent accuracy [12].

\section{Results}

\section{Changes in dental arch area}

Results show that the mean increase in maxillary dental arch area from T0 to T1 in the headgear group was $10.0 \%(95 \%$ confidence interval $[\mathrm{CI}] 5.6-14.4, p<0.001)$ and that there was no change in the control group $(0.0 \%, 95 \% \mathrm{CI}-2.7$ to $2.6, p<0.001)$. The mean increase in the mandibular dental arch area from T0 to $\mathrm{T} 1$ in the headgear group was 5.5\% $(95 \%$ CI $2.6-8.4, p<0.001)$ and there was a $2.4 \%(95 \% \mathrm{CI}$ -4.7 to $-0.1, p<0.001)$ reduction in the control group in the same time period. Therefore, there was a difference of 7.9 percentage points between the headgear and the control group with respect to the change of the mandibular dental arch area at T1. From T0 to T2 the maxillary area mean change in the headgear group was $12.3 \%$ (95\% CI $8.3-16.3, p<0.001)$ and the mandibular area mean change was $4.2 \%$ (95\% CI $0.2-8.3, p<0.001)$, respectively. In the control group, the change of the maxillary dental arch area was $1.3 \%(95 \% \mathrm{CI}-2.7$ to $5.2, p<0.001)$ and $-5.6 \%(95 \%$ CI -8.6 to $-2.6, p<0.001)$ in the mandibular dental arch area (Table 2). The difference between the male and female groups was also studied and the results showed that there was no significant difference between the genders.

The differences between the maxillary and mandibular dental arch areas from T0 to T1 and T2 are shown in Table 3 and in Fig. 3. Dental arch shape and difference in size at T2 are shown in Fig. 4. At the beginning of the study, no significant difference was found between the headgear group and the control group. At T1, the difference between the maxillary and mandibular dental arch areas was 34.9\% (95\% CI 29.8-40.0) in the headgear group and $27.5 \%$ (95\% CI $24.0-31.0)$ in the control group $(p=0.014)$. At T2, the difference between the maxillary and mandibular dental arch areas was 36.3\% (95\% CI 31.3-41.2) in the headgear group and $32.1 \%$ (95\% CI 27.1-37.1) in the control group.

\section{Changes in dental arch transversal dimensions}

All the transversal dimensions in the headgear and the control group from $\mathrm{T} 0$ to $\mathrm{T} 1$ and $\mathrm{T} 2$ were significantly increased $(p<0.05)$ except for the transversal dimension at the canine to canine level (Table 4). In the headgear group, 
Table 2 Changes in mean mandibular and maxillary dental arch area at T0, T1, and T2 in the headgear and control groups

Tab. 2 Veränderungen der mittleren Unterkiefer- und Oberkieferzahnbogenfläche bei T0, T1 und T2 in den Headgear- und Kontrollgruppen

\begin{tabular}{|c|c|c|c|c|c|c|c|c|c|}
\hline \multirow[b]{2}{*}{ T0-T1 } & \multicolumn{4}{|c|}{ Headgear } & \multicolumn{5}{|c|}{ Control } \\
\hline & $N$ & $\begin{array}{l}\text { Dental arch area } \\
\text { mean change, \% }\end{array}$ & $\begin{array}{l}\text { SD, } \\
\%\end{array}$ & $95 \% \mathrm{CI}$ & $N$ & $\begin{array}{l}\text { Dental arch area } \\
\text { mean change, \% }\end{array}$ & $\begin{array}{l}\text { SD, } \\
\%\end{array}$ & $95 \% \mathrm{CI}$ & $p$ \\
\hline $\begin{array}{l}\mathrm{M}+\mathrm{F}, \text { maxil- } \\
\text { lary }\end{array}$ & 26 & 10 & 11 & $5.6-14.4$ & 34 & 0 & 7.6 & -2.7 to 2.6 & $<0.001$ \\
\hline $\begin{array}{l}\mathrm{M}+\mathrm{F} \\
\text { mandibular }\end{array}$ & 25 & 5.5 & 7 & $2.6-8.4$ & 33 & -2.4 & 6.6 & $\begin{array}{l}-4.7 \text { to } \\
-0.1\end{array}$ & $<0.001$ \\
\hline $\begin{array}{l}\text { Male, maxil- } \\
\text { lary }\end{array}$ & 14 & 11.8 & 9.3 & $6.4-17.2$ & 20 & 1.1 & 5.7 & -1.5 to 3.8 & $<0.001$ \\
\hline $\begin{array}{l}\text { Male, } \\
\text { mandibular }\end{array}$ & 14 & 4.8 & 6.6 & $1.0-8.6$ & 19 & -1.8 & 6.6 & -5.0 to 1.4 & 0.008 \\
\hline $\begin{array}{l}\text { Female, max- } \\
\text { illary }\end{array}$ & 12 & 7.9 & 12.7 & -0.2 to 16 & 14 & -1.6 & 9.8 & -7.3 to 4.0 & 0.041 \\
\hline $\begin{array}{l}\text { Female, } \\
\text { mandibular }\end{array}$ & 11 & 6.4 & 7.7 & $1.2-11.6$ & 14 & -3.2 & 6.7 & -7.1 to 0.7 & 0.003 \\
\hline T0-T2 & $N$ & $\begin{array}{l}\text { Dental arch area } \\
\text { mean change, } \%\end{array}$ & $\begin{array}{l}\text { SD, } \\
\%\end{array}$ & $95 \% \mathrm{CI}$ & $N$ & $\begin{array}{l}\text { Dental arch area } \\
\text { mean change, } \%\end{array}$ & $\begin{array}{l}\text { SD, } \\
\%\end{array}$ & $95 \% \mathrm{CI}$ & $p$ \\
\hline $\begin{array}{l}\mathrm{M}+\mathrm{F}, \text { maxil- } \\
\text { lary }\end{array}$ & 25 & 12.3 & 9.7 & $8.3-16.3$ & 33 & 1.3 & 11.1 & -2.7 to 5.2 & $<0.001$ \\
\hline $\begin{array}{l}\mathrm{M}+\mathrm{F}, \\
\text { mandibular }\end{array}$ & 24 & 4.2 & 9.6 & $0.2-8.3$ & 30 & -5.6 & 8 & $\begin{array}{l}-8.6 \text { to } \\
-2.6\end{array}$ & $<0.001$ \\
\hline $\begin{array}{l}\text { Male, maxil- } \\
\text { lary }\end{array}$ & 15 & 12 & 10.4 & $6.3-17.8$ & 20 & 3.6 & 8.4 & -0.3 to 7.5 & 0.012 \\
\hline $\begin{array}{l}\text { Male, } \\
\text { mandibular }\end{array}$ & 13 & 5.8 & 9 & $\begin{array}{l}-0.4 \text { to } \\
11.2\end{array}$ & 19 & -4.4 & 8.7 & $\begin{array}{l}-8.6 \text { to } \\
-0.2\end{array}$ & 0.003 \\
\hline $\begin{array}{l}\text { Female, max- } \\
\text { illary }\end{array}$ & 10 & 12.6 & 9.2 & $6.0-19.2$ & 13 & -2.3 & 14 & $\begin{array}{l}-10.8 \text { to } \\
6.2\end{array}$ & 0.008 \\
\hline $\begin{array}{l}\text { Female, } \\
\text { mandibular }\end{array}$ & 11 & 2.4 & 10.4 & $\begin{array}{l}-4.6 \text { to } \\
9.4\end{array}$ & 11 & -7.7 & 6.5 & $\begin{array}{l}-12.1 \text { to } \\
-3.3\end{array}$ & 0.013 \\
\hline
\end{tabular}

$S D$ standard deviation, $T 0$ beginning of treatment, $T 1$ 2-year follow-up, $T 2$ 4-year follow-up, $M$ male, $F$ female, $95 \%$ CI $95 \%$ confidence interval

Table 3 Differences between mean mandibular and maxillary dental arch areas at T0, T1, T2, and between headgear and control groups

Tab. 3 Unterschiede zwischen mittleren Unterkiefer- und Oberkieferzahnbogenbereichen bei T0, T1, T2 und zwischen Headgear- und Kontrollgruppen

\begin{tabular}{|c|c|c|c|c|c|c|c|c|c|}
\hline \multirow[b]{2}{*}{$\mathrm{T} 0-\mathrm{T} 2$} & \multicolumn{4}{|c|}{ Headgear } & \multicolumn{4}{|c|}{ Control } & \multirow[b]{2}{*}{$p$} \\
\hline & $N$ & $\begin{array}{l}\text { Max/Mand mean differ- } \\
\text { ence, } \%\end{array}$ & $\mathrm{SD}, \%$ & $95 \% \mathrm{CI}$ & $N$ & $\begin{array}{l}\text { Max/Mand mean differ- } \\
\text { ence, } \%\end{array}$ & $\mathrm{SD}, \%$ & $95 \% \mathrm{CI}$ & \\
\hline T0 & 27 & 26.0 & 10.7 & $21.8-30.2$ & 34 & 24.5 & 11.7 & $20.5-28.6$ & 0.619 \\
\hline $\mathrm{T} 1$ & 26 & 34.9 & 12.6 & $29.8-40.0$ & 34 & 27.5 & 10.1 & $24.0-31.0$ & 0.014 \\
\hline $\mathrm{T} 2$ & 26 & 36.3 & 12.2 & $31.3-41.2$ & 31 & 32.1 & 13.6 & $27.1-37.1$ & 0.234 \\
\hline
\end{tabular}

95\% CI 95\% confidence interval, $T 0$ beginning of treatment, $T 1$ 2-year follow-up, T2 4-year follow-up, $M$ male, $F$ female, Max maxillary, Mand mandibular, $S D$ standard deviation

the transversal dimensions of the dental arch increased by an average of $9.8 \%(p<0.001)$ from T0 to T1 and $11.3 \%$ $(p<0.001)$ from T0 to T2 in the maxilla. In the mandible, the increases were $6.5 \%(p<0.001)$ and $7.1 \%(p<0.05)$, respectively. In the control group, the increases were $2.2 \%$ $(p<0.001)$ from T0 to $\mathrm{T} 1$ and $4.4 \%(p<0.001)$ from $\mathrm{T} 0$ to $\mathrm{T} 2$ in the maxilla and $0.5 \%(p<0.001)$ from $\mathrm{T} 0$ to $\mathrm{T} 1$ and $2.5 \%(p<0.05)$ from T0 to T2 in the mandible. The transversal dimension at the first premolar level in the maxillary dental arch increased by $10.4 \%$ (95\% CI 7.9-12.8) from $\mathrm{T} 0$ to $\mathrm{T} 1$ in the headgear group compared to $1.9 \%$
(95\% CI 0.0-3.8) increase in the control group showing a difference of 8.5 percentage points between the groups $(p<0.001)$. The transversal dimension at the first molar level in the maxillary dental arch increased by $9.5 \%$ (95\% CI 7.2-11.7) in the headgear group compared to $1.7 \%$ (95\% CI 0.3-3.1) increase in the control group from T0 to T1 showing a difference of 7.8 percentage points between the groups $(p<0.001)$. From T0 to T2 the increase in transversal dimension in the headgear group was in the maxilla 6.9 percentage points and in the mandible 4.6 percentage points larger on average in comparison to the control group. 
Fig. 3 Maxillary and mandibular dental arch area change at $\mathrm{T} 0, \mathrm{~T} 1$ and $\mathrm{T} 2$ with $95 \%$ confidence interval. Only positive or negative error bars are shown to avoid overlapping of the bars Abb. 3 Veränderung des Zahnbogenbereichs im Ober- und Unterkiefer bei T0, T1 und T2 mit $95 \%$-Konfidenzintervall. Um Überlappungen der Balken zu vermeiden, werden nur positive bzw. negative Fehlerbalken angezeigt

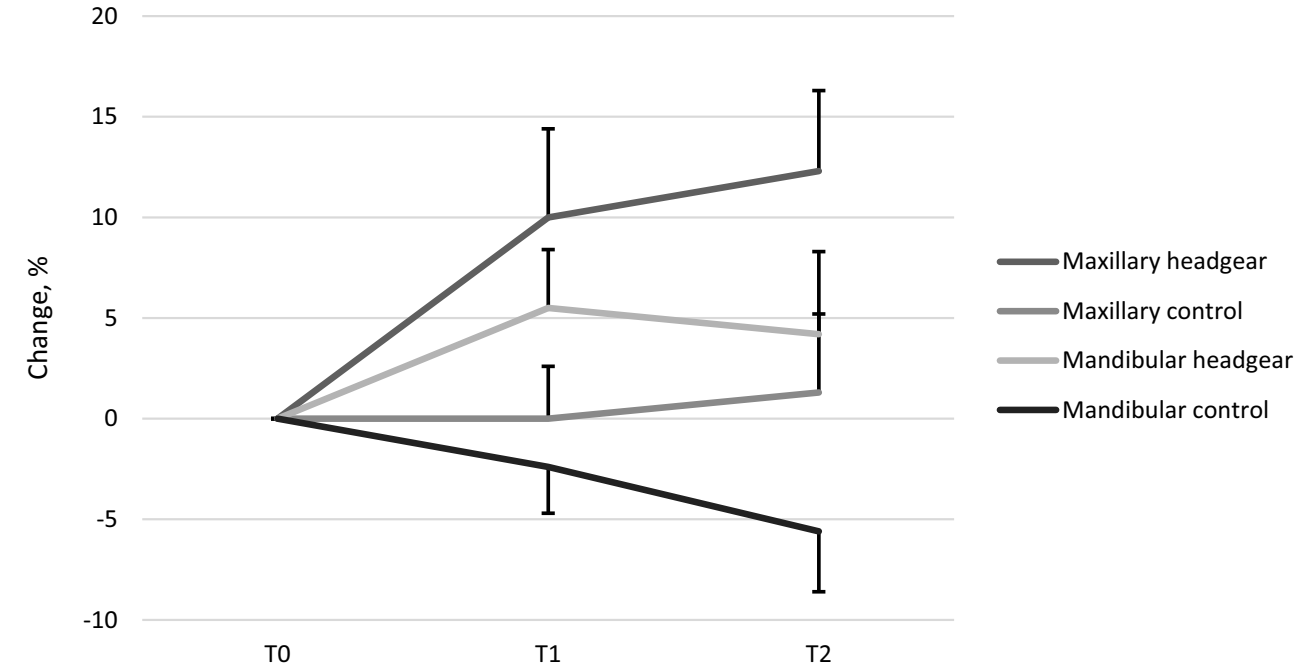

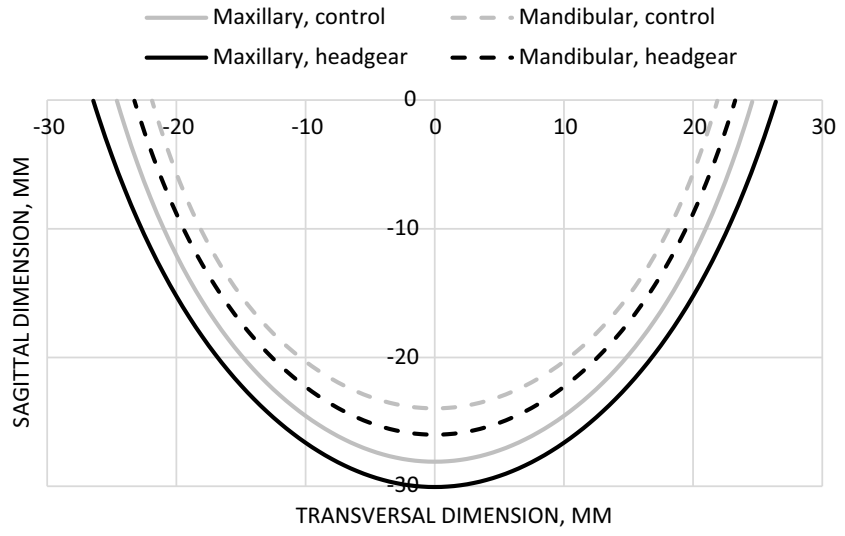

Fig. 4 Mean dental arches of both sexes combined at T2. Dental arch area calculated using the polynomial equation $y=A x^{6}+B x^{2}$. Maxillary and mandibular dental arches of the headgear group are larger compared to the control group

Abb. 4 Mittlere Zahnbögen von Patienten beider Geschlechter kombiniert bei T2. Zahnbogenfläche berechnet mit der Polynomgleichung $y=A x^{6}+B x^{2}$. Ober- und Unterkieferzahnbögen der Headgear-Gruppe sind größer als in der Kontrollgruppe

\section{Changes in dental arch sagittal dimensions}

The mean sagittal increase was larger in both the maxillary and mandibular dental arches and also from $\mathrm{T} 0$ to $\mathrm{T} 1$ and $\mathrm{T} 2$ in the headgear group in comparison to the control group (Table 5). The mean maxillary sagittal dimension between the incisors and the first molars increased by $4.3 \%$ (95\% CI $1.1-7.4)$ in the headgear group and decreased by $1.1 \%(95 \%$ CI -2.8 to 0.6 ) in the control group at $\mathrm{T} 1$ when compared to the starting point at $\mathrm{T} 0(p=0.002)$. At $\mathrm{T} 2$, the increase was $5.3 \%$ (95\% CI 2.8-7.9) in the headgear group compared to a decrease of $-0.8 \%$ (95\% CI -3.7 to 2.1$)$ in the control group ( $p=0.003$ ). The mean mandibular sagittal dimension between the incisors and the first molars increased by $1.9 \%$ (95\% CI 0.5-3.3) in the headgear group and decreased by
$1.8 \%$ (95\% CI -3.3 to -0.4$)$ in the control group from $\mathrm{T} 0$ to $\mathrm{T} 1(p=0.001)$. At T2, the increase was $0.5 \%(95 \% \mathrm{CI}$ -1.6 to 2.6) in the headgear group compared to a decrease of $4.4 \%$ (95\% CI -7.1 to -1.6$)$ in the control group $(p=0.009)$.

\section{Discussion}

It has been shown that by using the polynomial equation $y=A x^{6}+B x^{2}$ it is possible to study the shape and area of the dental arch. The use of this equation has earlier been shown to be reliable to analyze dental arch form and size [10]. Both the maxillary and mandibular dental arches of the headgear group showed a significant increase in area compared to the control group. From T0 to T2 the maxillary area mean change in the headgear group was $12.3 \%$ and the mandibular area mean change was $4.2 \%$ respectively. In the control group, the maxillary dental arch area increased only by $1.3 \%$ and the mandibular dental arch area decreased by 5.6\%. More increase can be seen in both the maxillary and mandibular dental arch areas in the headgear group compared to the control group. McDonald et al. [3] and Mäntysaari et al. [6] have expressed similar results in their studies. The work of Mäntysaari et al. [6] was based on the same material as the present study and they showed that the space gain in the mandible was approximately half of the space gain in the maxilla which is confirmed by the results of our study. However, in the former studies the dental arch area was not studied. In both the headgear and control groups, a slight decrease in mandibular dental arch area was seen from T1 to T2. However, the decrease was lower in the headgear group. The decrease in area might be explained by some relapse caused by insufficient use of the retention appliances, which would have prevented or decreased dental relapse [13]. There was a difference in increase between the mean mandibular and maxillary dental 
Table 4 Mean transversal dimension of the dental arch compared at canine-canine, 1st premolar-1st premolar, 2nd premolar-2nd premolar, 1st molar-1st molar level between headgear and control groups at T0-T1 and at T0-T2

Tab. 4 Mittlere transversale Dimension des Zahnbogens im Vergleich zwischen Headgear- und Kontrollgruppe bei T0-T1 und bei T0-T2 auf der Höhe von Eckzahn - Eckzahn, 1. Prämolar - 1. Prämolar, 2. Prämolar - 2 Prämolar, 1. Molar - 1. Molar

\begin{tabular}{|c|c|c|c|c|c|c|c|c|c|c|c|}
\hline \multirow{3}{*}{$\begin{array}{l} \\
\text { Maxillary, } \\
\text { T0-T1 }\end{array}$} & \multicolumn{5}{|c|}{ Headgear } & \multicolumn{6}{|c|}{ Control } \\
\hline & \multirow[t]{2}{*}{$N$} & \multicolumn{2}{|c|}{$\begin{array}{l}\text { Transversal mean } \\
\text { change }\end{array}$} & \multirow[t]{2}{*}{$\begin{array}{l}\text { SD, } \\
\%\end{array}$} & \multirow[t]{2}{*}{$95 \%$ CI } & \multirow[t]{2}{*}{$\bar{N}$} & \multicolumn{2}{|c|}{$\begin{array}{l}\text { Transversal mean } \\
\text { change }\end{array}$} & \multirow[t]{2}{*}{$\begin{array}{l}\text { SD, } \\
\%\end{array}$} & \multirow[t]{2}{*}{$95 \% \mathrm{CI}$} & \multirow[t]{2}{*}{$\bar{p}$} \\
\hline & & $\%$ & Mm & & & & $\%$ & Mm & & & \\
\hline Canine & 20 & 11 & 3.4 & 7.3 & $7.6-14.4$ & 21 & 3 & 0.9 & 6.4 & $0.1-6.0$ & 0.001 \\
\hline $\begin{array}{l}\text { 1st Premo- } \\
\text { lar }\end{array}$ & 23 & 10.4 & 3.9 & 5.7 & $7.9-12.8$ & 26 & 1.9 & 0.7 & 4.8 & $0.0-3.8$ & $<0.001$ \\
\hline $\begin{array}{l}\text { 2nd Premo- } \\
\text { lar }\end{array}$ & 25 & 8.1 & 3.5 & 4.6 & $6.2-10.0$ & 31 & 2 & 0.8 & 4.4 & $0.4-3.6$ & $<0.001$ \\
\hline 1st Molar & 26 & 9.5 & 4.6 & 5.6 & $7.2-11.7$ & 34 & 1.7 & 0.8 & 4 & $0.3-3.1$ & $<0.001$ \\
\hline \multirow[t]{2}{*}{$\begin{array}{l}\text { Maxillary, } \\
\text { T0-T2 }\end{array}$} & $N$ & \multicolumn{2}{|c|}{$\begin{array}{l}\text { Transversal mean } \\
\text { change }\end{array}$} & $\begin{array}{l}\text { SD, } \\
\%\end{array}$ & $95 \% \mathrm{CI}$ & $N$ & \multicolumn{2}{|c|}{$\begin{array}{l}\text { Transversal mean } \\
\text { change }\end{array}$} & $\begin{array}{l}\text { SD, } \\
\%\end{array}$ & $95 \% \mathrm{CI}$ & $p$ \\
\hline & & $\%$ & Mm & & & & $\%$ & Mm & & & \\
\hline Canine & 21 & 11.3 & 3.5 & 9.1 & $7.1-15.4$ & 21 & 7.3 & 2.3 & 7 & $4.1-10.5$ & 0.124 \\
\hline $\begin{array}{l}\text { 1st Premo- } \\
\text { lar }\end{array}$ & 21 & 13.9 & 5.3 & 6.8 & $10.8-17.0$ & 27 & 5.7 & 2.1 & 5.7 & $3.5-8.0$ & $<0.001$ \\
\hline $\begin{array}{l}\text { 2nd Premo- } \\
\text { lar }\end{array}$ & 21 & 10.5 & 4.4 & 4.7 & $8.4-12.7$ & 28 & 4.3 & 1.8 & 5 & $2.3-6.2$ & $<0.001$ \\
\hline 1st Molar & 24 & 9.6 & 4.5 & 4.4 & $7.8-11.5$ & 33 & 3.2 & 1.5 & 4.8 & $1.5-4.9$ & $<0.001$ \\
\hline \multirow[t]{2}{*}{$\begin{array}{l}\text { Mandibular, } \\
\text { T0-T1 }\end{array}$} & $N$ & \multicolumn{2}{|c|}{$\begin{array}{l}\text { Transversal mean } \\
\text { change }\end{array}$} & $\begin{array}{l}\text { SD, } \\
\%\end{array}$ & $95 \%$ CI & $N$ & \multicolumn{2}{|c|}{$\begin{array}{l}\text { Transversal mean } \\
\text { change }\end{array}$} & $\begin{array}{l}\text { SD, } \\
\%\end{array}$ & $95 \%$ CI & $p$ \\
\hline & & $\%$ & Mm & & & & $\%$ & Mm & & & \\
\hline Canine & 20 & 6.8 & 1.7 & 6.3 & $3.8-9.7$ & 16 & 3.2 & 0.8 & 5 & $0.5-5.9$ & 0.074 \\
\hline $\begin{array}{l}\text { 1st Premo- } \\
\text { lar }\end{array}$ & 21 & 6.5 & 2.1 & 6.1 & $3.7-9.3$ & 29 & 0.6 & 0.2 & 4.7 & -1.2 to 2.3 & $<0.001$ \\
\hline $\begin{array}{l}\text { 2nd Premo- } \\
\text { lar }\end{array}$ & 25 & 6.2 & 2.4 & 2.8 & $5.1-7.4$ & 31 & 0.4 & 0.2 & 2.1 & -0.4 to 1.1 & $<0.001$ \\
\hline 1st Molar & 25 & 6.8 & 3.0 & 3.5 & $5.3-8.2$ & 33 & 0.6 & 0.3 & 2.3 & -0.2 to 1.4 & $<0.001$ \\
\hline \multirow[t]{2}{*}{$\begin{array}{l}\text { Mandibular, } \\
\text { T0-T2 }\end{array}$} & $N$ & \multicolumn{2}{|c|}{$\begin{array}{l}\text { Transversal mean } \\
\text { change }\end{array}$} & $\begin{array}{l}\text { SD, } \\
\%\end{array}$ & $95 \% \mathrm{CI}$ & $N$ & \multicolumn{2}{|c|}{$\begin{array}{l}\text { Transversal mean } \\
\text { change }\end{array}$} & $\begin{array}{l}\text { SD, } \\
\%\end{array}$ & $95 \% \mathrm{CI}$ & $p$ \\
\hline & & $\%$ & Mm & & & & $\%$ & Mm & & & \\
\hline Canine & 21 & 4.6 & 1.1 & 8.2 & $0.8-8.3$ & 24 & 5.2 & 1.3 & 7.3 & $2.1-8.3$ & 0.797 \\
\hline $\begin{array}{l}\text { 1st Premo- } \\
\text { lar }\end{array}$ & 22 & 8.7 & 2.9 & 7.3 & $5.5-12.0$ & 26 & 4.7 & 1.5 & 4.9 & $2.7-6.7$ & 0.029 \\
\hline $\begin{array}{l}\text { 2nd Premo- } \\
\text { lar }\end{array}$ & 23 & 6.4 & 2.6 & 4 & $4.7-8.1$ & 28 & 2.2 & 0.8 & 4.7 & $0.4-4.0$ & 0.001 \\
\hline 1st Molar & 25 & 6.3 & 3.0 & 3.7 & 4.8-7.9 & 30 & 0.7 & 0.3 & 4.3 & -0.9 to 2.3 & $<0.001$ \\
\hline
\end{tabular}

$S D$ standard deviation, $95 \%$ CI 95\% confidence interval, $T 0$ beginning of treatment, $T 1$ 2-year follow-up, $T 2$ 4-year follow-up

arch areas from T0 to T2 in both groups. The change was greater in the headgear group. This is a normal outcome of headgear treatment because the force of the headgear is transmitted directly to the maxilla. In the maxilla, treating crowding with the headgear alone is successful in many cases. But in the mandible, headgear treatment may not be enough for treating severe crowding.

The increase in transversal dimension in the headgear group appeared higher than in the control group at all measured levels, in both dental arches. In the headgear group the dental arch transversal dimension increased by an average of $11.3 \%$ from T0 to T2 in the maxilla. In the control group, the average increase was only $4.4 \%$ in the maxilla. The mean sagittal dimension increase was also greater in both the maxillary and mandibular dental arch and from T0 to $\mathrm{T} 1$ and from $\mathrm{T} 0$ to $\mathrm{T} 2$ in the headgear group in comparison with the control group. Freitas et al. [4] have expressed the view that the increased sagittal dimension is achieved by distalizing the first molars and inhibiting the forward growth of the maxilla. However, with respect to this measurement, only the incisor to the first molar sagittal dimension was statistically significant. Thus, no conclusions can be made regarding the sagittal relations for other measured teeth. 
Table 5 Mean changes in sagittal dimension between incisor-1st molar level between headgear and control groups from T0-T1 and from T0-T2 Tab. 5 Mittlere Veränderungen in der Sagittalebene zwischen Headgear- und Kontrollgruppen von T0-T1 und von T0-T2, Höhe Eckzahn bis erster Molar

\begin{tabular}{|c|c|c|c|c|c|c|c|c|c|c|c|}
\hline \multirow{3}{*}{$\begin{array}{l}\text { Dental arch, } \\
\text { time period }\end{array}$} & \multicolumn{5}{|c|}{ Headgear } & \multicolumn{5}{|c|}{ Control } & \multirow{3}{*}{$p$} \\
\hline & \multirow[t]{2}{*}{$\bar{N}$} & \multicolumn{2}{|c|}{ Sagittal mean change } & \multirow{2}{*}{$\begin{array}{l}\mathrm{SD}, \\
\%\end{array}$} & \multirow[t]{2}{*}{$95 \% \mathrm{CI}$} & \multirow[t]{2}{*}{$\bar{N}$} & \multicolumn{2}{|c|}{$\underline{\text { Sagittal mean change }}$} & \multirow{2}{*}{$\begin{array}{l}\text { SD, } \\
\%\end{array}$} & \multirow[t]{2}{*}{$95 \% \mathrm{CI}$} & \\
\hline & & $\%$ & $\mathrm{Mm}$ & & & & $\%$ & $\mathrm{Mm}$ & & & \\
\hline $\begin{array}{l}\text { Maxillary, } \\
\text { T0-T1 }\end{array}$ & 26 & 4.3 & 1.2 & 7.8 & $1.1-7.4$ & 34 & -1.1 & -0.3 & 4.9 & -2.8 to 0.6 & 0.002 \\
\hline $\begin{array}{l}\text { Maxillary, } \\
\text { T0-T2 }\end{array}$ & 25 & 5.3 & 1.4 & 6.2 & $2.8-7.9$ & 33 & -0.8 & -0.2 & 8.1 & -3.7 to 2.1 & 0.003 \\
\hline $\begin{array}{l}\text { Mandibular, } \\
\text { T0-T1 }\end{array}$ & 25 & 1.9 & 0.5 & 3.4 & $0.5-3.3$ & 33 & -1.8 & -0.5 & 4.1 & $\begin{array}{l}-3.3 \text { to } \\
-0.4\end{array}$ & $<0.001$ \\
\hline $\begin{array}{l}\text { Mandibular, } \\
\text { T0-T2 }\end{array}$ & 24 & 0.5 & 0.1 & 5.1 & -1.6 to 2.6 & 30 & -4.4 & -1.1 & 7.4 & $\begin{array}{l}-7.1 \text { to } \\
-1.6\end{array}$ & 0.009 \\
\hline
\end{tabular}

$S D$ standard deviation, 95\% CI 95\% confidence interval, $T 0$ beginning of treatment, $T 1$ at 2-year follow-up, $T 2$ at the 4-year follow-up

The polynomial equation can be used to visualize the dental arches. In the headgear group, both the maxillary and mandibular dental arches were larger compared to the control group. Even though the mean dental arch area can be calculated from the polynomial equation, it cannot be used to accurately calculate sagittal or transversal dimensions of the dental arch at any specific levels as it is only an estimation of the overall dental arch. Therefore, specific measurement points were used to calculate the sagittal and transversal dimensions in this study.

In the present study, the headgear treatment was initiated earlier than in most other studies [14-16]. It is interesting that in the study of Julku et al. [17] where early or later headgear treatment was compared, a larger effect was achieved in the dental arches in the early treatment group. When the treatment effect was compared between the genders, a larger effect was seen in boys. One possible explanation for this could be that boys and girls were in a different maturation phase [18]. When maximal space gain is the goal of the headgear treatment, early onset of treatment could be beneficial, especially before eruption of the second molars.

As can be seen from the results, the headgear is an effective treatment method for gaining space in the dental arches. The headgear increased dental arch area in the maxilla and in the mandible, even though the force is transmitted directly to maxilla. In mild cases, the space gain in the mandible may be enough and no other treatment is required after headgear treatment. The results also show that there was little to no relapse in the maxillary transversal dimension after headgear treatment and the dental arch area remained stable or even continued to increase after headgear treatment. In the mandible, however, relapse could be seen after headgear treatment. Even though some relapse occurred in the mandible in both the headgear group and the control group, the difference between these groups remained significant.

\section{Conclusions}

This study supports using the polynomial equation $y=A x^{6}+B x^{2}$ to study and visualize changes in shape and area of the dental arch. The results show that the headgear is an effective treatment for gaining space in the dental arches. In addition, the results show that when used as an early phase treatment, the relapse is relatively small compared to the gained space.

Funding This study was supported financially by the funds from Finnish Dental Society Apollonia and European Orthodontic Society.

Funding Open access funding provided by University of Oulu including Oulu University Hospital.

\section{Compliance with ethical guidelines}

Conflict of interest T. Heino, H. Kokko, V. Vuollo and P. Pirttiniemi declare that they have no competing interests.

Ethical standards All procedures performed in studies involving human participants were in accordance with the 1964 Helsinki declaration and its later amendments or comparable ethical standards. Ethics committee approval was not required for the type of study that was initiated in 1992. The law of ethics committees in Finland was given in 1999, after which the ethics committee approval became mandatory. Written informed consent to participate was obtained from the parents of all patients in the study.

Open Access This article is licensed under a Creative Commons Attribution 4.0 International License, which permits use, sharing, adaptation, distribution and reproduction in any medium or format, as long as you give appropriate credit to the original author(s) and the source, provide a link to the Creative Commons licence, and indicate if changes were made. The images or other third party material in this article are included in the article's Creative Commons licence, unless indicated otherwise in a credit line to the material. If material is not included in the article's Creative Commons licence and your intended use is not permitted by statutory regulation or exceeds the permitted use, you will need to obtain permission directly from the copyright holder. To view a copy of this licence, visit http://creativecommons.org/licenses/by/4. $0 /$. 


\section{References}

1. Burhan AS (2013) Combined treatment with headgear and the Frog appliance for maxillary molar distalization: a randomized controlled trial. Korean J Orthod 43(2):101-109

2. Godt A, Berneburg M, Kalwitzki M, Goz G (2008) Cephalometric analysis of molar and anterior tooth movement during cervical headgear treatment in relation to growth patterns. J Orofac Orthop 69(3): 189-200

3. McDonald JL, Shofer FS, Ghafari J (2001) Effect of molar rotation on arch length. Clin Orthod Res 4(2):79-85

4. Freitas MR, Lima DV, Freitas KM, Janson G, Henriques JF (2008) Cephalometric evaluation of Class II malocclusion treatment with cervical headgear and mandibular fixed appliances. Eur J Orthod 30(5):477-482

5. Kirjavainen M, Kirjavainen T, Haavikko K (1997) Changes in dental arch dimensions by use of an orthopedic cervical headgear in Class II correction. Am J Orthod Dentofacial Orthop 111(1):59-66

6. Mantysaari R, Kantomaa T, Pirttiniemi P, Pykalainen A (2004) The effects of early headgear treatment on dental arches and craniofacial morphology: a report of a 2-year randomized study. Eur J Orthod 26(1):59-64

7. Tulloch JF, Phillips C, Proffit WR (1998) Benefit of early Class II treatment: progress report of a two-phase randomized clinical trial. Am J Orthod Dentofacial Orthop 113(1):62-72

8. Shpack N, Brosh T, Mazor Y, Shapinko Y, Davidovitch M, Sarig R et al (2014) Long- and short-term effects of headgear traction with and without the maxillary second molars. Am J Orthod Dentofacial Orthop 146(4):467-476

9. Pirttiniemi P, Kantomaa T, Mantysaari R, Pykalainen A, Krusinskiene V, Laitala $\mathrm{T}$ et al (2005) The effects of early headgear treat- ment on dental arches and craniofacial morphology: an 8-year report of a randomized study. Eur J Orthod 27(5):429-436

10. Noroozi H, Nik TH, Saeeda R (2001) The dental arch form revisited. Angle Orthod 71(5):386-389

11. Park J, Baumrind S, Curry S, Carlson SK, Boyd RL, Oh H (2019) Reliability of 3D dental and skeletal landmarks on CBCT images. Angle Orthod 89(5):758-767

12. Kiviahde H, Bukovac L, Jussila P, Pesonen P, Sipilä K, Raustia A, Pirttiniemi $P$ (2018) Inter-arch digital model vs. manual cast measurements: accuracy and reliability. Cranio 36(4):222-227

13. Keeling SD, Wheeler TT, King GJ, Garvan CW, Cohen DA, Cabassa $S$ et al (1998) Anteroposterior skeletal and dental changes after early Class II treatment with bionators and headgear. Am J Orthod Dentofacial Orthop 113(1):40-50

14. Fenderson FA, McNamara JA Jr, Baccetti T, Veith CJ (2004) A long-term study on the expansion effects of the cervical-pull facebow with and without rapid maxillary expansion. Angle Orthod 74(4):439-449

15. King GJ, Keeling SD, Hocevar RA, Wheeler TT (1990) The timing of treatment for Class II malocclusions in children: a literature review. Angle Orthod 60(2):87-97

16. Tulloch JF, Proffit WR, Phillips C (2004) Outcomes in a 2-phase randomized clinical trial of early Class II treatment. Am J Orthod Dentofac Orthop 125(6):657-667

17. Julku J, Hannula M, Pirilä-Parkkinen K, Tolvanen M, Pirttiniemi P (2019) Dental arch effects after early and later timed cervical headgear treatment-a randomized controlled trial. Eur J Orthod 41(6):622-630

18. Hoffmann J, Krey KF, Hirsch C (2013) Pubertal status of children and adolescents during orthodontic treatment. J Orofac Orthoped 74(3):257-264 